\title{
Religiosity and Political Participation of University Students in Turkey
}

\author{
Özlem Altunsu Sönmez \\ Dr. Selçuk University, Faculty of Arts \\ Department of Sociology, ozlemaltunsu @gmail.com
}

\section{Doi:10.5901/mjss.2013.v4n10p403}

\begin{abstract}
This research aims to analyze the religiosity and political participation of the university students in Turkey. For this aim, a survey conducted on 872 students in order to understand the impact of religiosity on political participation. In this research, political participation is measured as conventional and un-conventional participation forms. The scale is prepared as 13 questions; 7 of them for measuring conventional and 6 of them for measuring un-conventional participation. It is determined in the literature that religiosity is related to conventional political participation and also has a negative effect on un-conventional participation. In fact, the studies included in the literature show that participation of the religious individuals is low generally and if they choose to perform any political participation, it is realized in the form of conventional participation. On the other hand university students are associated more than any groups with un-conventional participation. According to the result of the research it has been found that religiosity has a negative correlation with both conventional and un-conventional form of political participation.
\end{abstract}

Keywords: Religiosity, political participation, university students, Turkey

\section{Introduction}

The main objective of this research is to determine the effects of being religious or non-religious on political participation and how being religious differs generally and the role of religiosity on conventional and un-conventional forms of political participation of university students in Turkey specifically. In the literature, it is known that religiosity decreases political participation and the participation of the religious people is rather conventional. Based on this view, it is expected that religiosity would decrease political participation in this study.

Religion and religiosity are the concepts which are not easily defined up to the present. Not only defining the religion or religiosity but also measuring religiosity is also very problematic. Hökelekli points out that since there is no single form of religiosity, individuals believing in the same religion, even included in the same religious group, are different and for this reason, it is possible to mention a religiosity specific to every individual. Thus, this makes defining religiosity even much harder (Hökelekli, 2010: 81). In addition, Allport indicates that there are as many kinds of religion experiences as the number of people who tend to be religious in the world (Allport, 2004: 46). Similarly Spilka et al. says that "there is obviously great overlap among the various proposals, but all agree on one thing: Even though there may be only one word of religion, there may be hundred possible ways of being religious" (Spilka et al., 1985: 7). In this respect, Fromm states another situation that is related to this issue. He argues that, it is extremely difficult to understand whether someone is religious or not. According to him, although some people claim that they are religious, they may not be religious internally, and people who say that they are not religious may act highly religiously (Fromm, 1997: 239). It is understand from this argument that the problem lies not only at defining religiosity, but also at measuring religiosity, as well. As a result, every study makes a definition in accordance with its own research subject and in parallel with the discipline it is included. A researcher who is interested in the issue of religion and who desires to conduct a comprehensive research on the issue would unavoidably encounter the problem of measuring religiosity and many more problems included in it someday (Vernon, 1962a: 159). According to Vernon while try to measure religiosity there are two approaches. In the first approach such criteria such as church membership, church attendance, or acceptance of specific beliefs are often used to measure religiosity. In the second one, researcher asks to respondents some questions such as "how interested they are in religion or how important they feel religion to be in their lives" in order to measure religiosity (Vernon, 1962b: 243-244). Briefly it could be argued that for this research religiosity means to believe in a religion and to live the life in accordance with the requirements of that religion. Accordingly to this, religiosity is measured by asking to the respondents as how they feel themselves to be religious. 
Another concept of the study, political participation has started to gain importance from the second half of the 20th century with people's beginning to take part in the political life, and has become a subject matter on which political scientists study intensively. In that era, democratic thinking gained importance and the idea of constructing political power on large masses instead of an intangible minority isolated from people is observed. In this respect, political participation is a concept that emerged as a result of the modernization process and as a component of modern societies. Just as the definitions of religion and religiosity, this concept also has been defined and interpreted differently by different researchers.

Aristotle defines the human being as a "political animal". Based on this quotation, it is possible to assume that human beings will take part in a political idea in some way or other. It is possible to express political participation as the attitudes and behaviors of the citizens towards the political system. Within this system, individuals perform some actions in order to affect directly or indirectly the decision-making of the political administrators. These actions may range from voting to participate in a candidate's campaign, to collect signatures, or participating in boycotts or meetings. In addition, individuals may follow political agenda via mass media or perform a political attitude and action by discussing political issues within their family or friends. So, it is also possible to say that not every individual performs the same level of participation. While some follow up the political agenda just as spectators, some others may prefer to take part in politics actively.

Political participation is defined differently by many researches. Some consider just voting as adequate for political participation, some others, nevertheless, state that campaign activity, protest behavior and volunteering should also be considered for political participation. First of all, Van Deth states as summarizing the situation that political participation is a wide-ranging concept and "has become a study of everything" (Van Deth, 2001: 2). Different forms of political participation were first started to be discussed by political scientists in 1960s-1970s (Milbrath, 1965; Verba and Nie, 1972; Barnes and Kaase, 1979). While Milbrath expressed that political participation was unidimensional, Barnes et al. (1979) mentioned two dimensions, namely conventional and un-conventional. Political participation was considered as unidimensional in 1950s and 1960s, but later it was studied as a multidimensional concept.

Barnes et al. (1979) divides political participation into two, namely conventional and unconventional. Conventional political participation is composed of actions in accordance with the rules and norms established by the political regime. Voting, participating in election campaigns, making donation to the election campaign of a candidate, being interested in politics, discussing political issues, wearing a badge of a political party, becoming a member of a political party or having conversation with political people are examples of such activities. On the other hand, unconventional political participation is composed of actions that are not in compliance with the rules and norms established by the political regime. Publishing leaflets, arranging demonstrations or meetings, forwarding collective petition, boycotting, and blocking building entrances/exits are examples of unconventional participation. Conventional political participation represents political actions accepted by the dominant culture while unconventional political participation involves the actions that are not considered acceptable by the dominant public culture, even if those actions are legal (Conway, 2000: 4).

There is no agreement on how political participation should be measured, either. There is no accurate answer to the questions such as how political participation is measured, with how many items it should be measured or how many dimensions it includes, etc. For this reason, every researcher decides on how to measure political participation and which questions to be asked by himself/herself.

\section{Literature Review}

\subsection{Religiosity}

When briefly looking at the studies on religiosity, it is seen that researchers review first of all what religiosity is and how it is measured, as well as the factors influencing the religiosity of the individual. Studies on religiosity have been reviewed theologically, psychologically, sociologically, anthropologically and politically by many social sciences. Religiosity has been discussed in many areas, ranging from the influence of religion and religiosity on the mental health to depression, from political participation to political attitudes and behaviors, even to criminal actions.

A part of the studies on religiosity is related with the factors which lead to occurrence of the religious behavior (Cornwall, 1989: 579-587). There are many influences that affect the people's religiousness in literature. In socialization parents, peer groups and religious institutions are the factors that influence the religiousness. Additionally, age, marital status, socio-economic status, gender is also some factors to determine people's religiousness. Parents have most important impact on child or adolescent religion. On the other hand, peers, education, school environment, the mass 
media, and reading have an affect but lesser than the parents (Hood et al., 2009: 125). In several studies family socialization were the most frequent answers that had an effect on student's religious beliefs and mother was more important than the father when we compare the two parents (Argyle and Beit-Hallahmi, 1975; Allport, 2004). Some studies on gender also show that women are more religious than men (Allport et. al. 1948; Batson et.al 1993; Miller and Hoffman 1995; Allport, 2004; Günay, 2006; Hökelekli, 2010).

Most of the religiosity studies in Turkey were applied to the university students (Mutlu, 1989; Mutlu, 1996; Uysal, 1996; Onay 1999; Şahin 1999; Onay; 2004; Çapcıoğlu 2009). There are very few studies that investigate the sociopolitical attitudes and religosity (Çapcıoğlu, 2009; Hülür and Kalender, 2003; Çarkoğlu and Toprak, 2006). Gender, age, occupation, socio-economic status, education, marital status, the place of accommodation, social class, urban and rural distinction, type of the group, its size, level of knowledge, economic status, political and social incidents, and being deprived of certain rights or benefits, alienation, exclusion and oppression are the factors affecting the individual's religiosity (Günay 2006; Hökelekli 2010). According to these studies, people living in the rural areas are more religious than the ones living in cities, married people are more religious than singles, women are more religious than men and the middle class are more religious than others. On the other hand, some other studies yielded exactly opposite results. In the studies of Köktaş (1993), Hülür and Kalender (2003), Onay (2004), and Mehmedoğlu (2004) men are found more religious than women. When analyzed at the relationship between social status and religiosity (Hökelekli, 2010; Köktaş, 1993; Onay, (2004), it can be also seen that the religiosity level of the people with higher socio-economic levels is lower than the people with middle and low socio-economic levels.

\section{Political Participation}

When studies conducted on political participation are reviewed, it is observed that the issue is investigated from a wide perspective. Political participation has been associated almost every subject matter. While some studies measure participation in different countries, the large majority of studies focus on the variables that determine political participation. Some studies investigate participation among young people whereas some others make comparative analyses in this area. As one of the most important variables of this study, religion also emerges as a variable that is investigated in relation with political participation.

According to most of the studies age is one of the most important determinant of political participation as age increases political participation increases, as well (Kalaycıoğlu, 1983; Dalton, 2002; Tatar, 2003, Quintelier, 2007, Gallup, 2007) Education is the other important factor that affects political participation in some studies. They indicate that more educated people ara more participated than the less educated (Kalaycıoğlu, 1983; Walter and Rosenberg, 2007; Quitelier, 2007; Gallup 2007). There has been found a positive relationship between gender and political participation in favor of men in the both national and international literature. Men tended to be found more politicaly active than women (Almod and Verba, 1963; Milbrath, 1965; Ozankaya, 1966; Baykal 1970; Wolfinger and Rosenstone, 1980; Kalaycıoğlu, 1983; Erdoğan, 2001; Conway, 2000; TÜSİAD, 2001; Tatar, 2003; Gallup, 2007). In difference of conventional and unconventional participation Esgin (1999) found female students performed conventional participation most while the men performed un-conventional participation. According to Parlak's research (1999) whereas unconventional participation is associated with relatively higher education un-conventional participation is associated with relatively lower education. In Turkey studies have found that the political participation level of students is very low (Parlak, 1999; Erdoğan). In addition, many studies have found a positive relationship between income and political participation (Almond and Verba 1963; Baykal, 1970; Verba and Nie, 1972; Wolfinger and Rosenstone, 1980, Kalaycıŏlu, 1983; Verba, et.al., 1995; Conway, 2000).

The relationship between religiosity and political participation has been investigated in the literature mostly on the basis of religious institutions. This has been made by reviewing mostly the relationship between membership and participation. It is determined in the literature that religiosity is related to conventional political participation and has a negative effect on unconventional participation. Çarkoğlu and Kalaycıoğlu (2009) found that religiosity had a diminishing effect on protest and pressure potentials. Also Erdoğan stated as a result of the regression analyses he conducted in his studies that religiosity was a determinant of conventional participation. Secret et al. (1990) investigated the relationship between religiosity and political participation in their study and as a result, it was determined that religiosity suppressed protest activities. In the studies conducted so far on political participation, religiosity has emerged as related to the conventional political participation. In fact, the studies included in the literature show that participation of the religious individuals is low and that if they choose to perform any political participation, it is realized in the form of conventional participation. 


\section{Methodology}

The descriptive survey research design was adopted for this study. 872 students from faculty of Arts and Sciences, Divinity and, Economic and Administrative Sciences from three universities were constituted the participants of this research in order to establish relationships between the religiosity and political participation. Data were collected by means of the group-administered questionnaire method.

In this research, respondents were asked about directly how much or to what degree they see themselves as religious in ten point likert scale ranging from 1 (low) to 10 (high). While 1 indicates no religiosity, 10 indicate 100\% of being religious. For measuring political participation, a scale was conducted by researcher. The scale is consisted of 13 questions while 7 of them measuring conventional and 6 of them for un-conventional participation. Conventional participation was measured with the questions; working in a campaign of a party or candidate, collect signature or signed a petition for supporting a candidate, wear a sticker or badge of a political party, persuade someone how to vote, youth branches of a political party, and political parties except youth branches. Due to the fact that voting is mandatory in Turkey, voting is not included in this form of political participation calculation. Un-conventional participation is measured by the question; writing a letter of application, signing a petition, joining a boycott, attending a political demonstration/meeting, participating in a protest march, organizing a demonstration, meeting, and protest march.

The reliability of the whole scale was checked by means of the cronbach alpha reliability test and the alpha result of the scale was found .824. The cronbach alpha value of conventional sub-scale was determined as .752 while the unconventional sub-scale was determined as .769. The KMO value of the scale is 0.869 and this indicates a good validity level. According to the results of the Bartlett test, it is significant with the level of 0.01 .

For analyzing the relation of religiosity and political participation hypotheses below are constructed.

$\mathrm{H} 1$ : There is a positive relationship between religiosity and conventional political participation.

$\mathrm{H} 2$ : There is a negative relationship between religiosity and un-conventional political participation.

\section{Findings}

Table 1 indicates the result of respondent's religiosity. As a result, religiosity mean of participant is found as 6.56 in10 point likert scale. The students in this research are found highly religious in comparison with the other studies about Turkey.

Table 1: Distribution of Results according to Religiosity Level

\begin{tabular}{cccccc}
\hline Religiosity & N & Min. & Max & Mean & Std. Dev. \\
\hline & 870 & 1 & 10 & 6.56 & 2.769 \\
\hline
\end{tabular}

In this study, political participation is measured by means of the 13 questions. It is seen that the respondents performed 'voting' most, as a form of political participation (75.8\%). It is followed by 'signing a petition' $49 \%$, 'writing a letter of application' $44.7 \%$. The lowest rate is belongs to 'member of political parties except youth branches' with the rate of $2.2 \%$. It would not be wrong to argue that the rate of cast a vote participation in young people is quite high. It is clearly seen from the table that university students performed un-conventional participation much more than conventional participation except voting. This situation is corresponding with the literature. These results are found higher than the other studies which are conducted in Turkey on political participation. Not yet choice is included in the study in order to see the political tendency of the participants who has not participated yet, due to underage or because of not having a chance.

Table 2: Distribution of Results according to Political Participation Scale

\begin{tabular}{l|ccc}
\hline \multirow{2}{*}{ Political participation } & Yes & No & Not Yet \\
\cline { 2 - 4 } & $\%$ & $\%$ & $\%$ \\
\hline 1. Voting in an election & 75.8 & 13.6 & 10.6 \\
2. Working in a campaign of a party or candidate & 6.8 & 84.7 & 8.5 \\
3. Collect signature/signed a petition for a candidate & 3.4 & 89.0 & 7.6 \\
4. Wear a sticker or badge of a political party. & 6.9 & 86.7 & 6.4 \\
5. Persuade someone how to vote & 21.2 & 72.8 & 0.6
\end{tabular}


6. Youth branches of a political party

7. Political parties except youth branches

8. Writing a letter of application to the authorities

9. Signing a petition

10. Joining a boycott

11. Attending a political demonstration/meeting

12. Participating in a protest march

13. Organizing a demonstration, meeting, protest march

$\begin{array}{ccc}4.9 & 88.2 & 6.9 \\ 2.2 & 94.0 & 3.8 \\ 44.7 & 33.6 & 21.7 \\ 49.0 & 38.6 & 12.4 \\ 27.3 & 61.9 & 10.8 \\ 27.4 & 64.6 & 0.8 \\ 30.3 & 58.3 & 11.5 \\ 5.0 & 85.2 & 9.7\end{array}$

Table 3 shows the result of political participation of university students in terms of their religiosity. Student's religiosity mean scores are found high mostly in the choice of 'not participate' when comparing only participate and not-participate choices; except voting, youth branches of a political party and organizing demonstrations and meeting. This finding show that religiosity decreases the students' political participation both conventional and un-conventional way.

The relationship among conventional, unconventional, total political participation and religiosity is investigated using Pearson product-moment correlation coefficient. Here, the respondents who stated 'not yet' are considered as not participated because of the fact that no participation has occurred yet. It is seen from the Table 4 that there is a negative correlation between religiosity and conventional political participation $r=-0.060, n=872, p<.0$, with high levels of religiosity associated with low levels of conventional political participation. Similarly there is a negative correlation between religiosity and un-conventional political participation, $r=-0.223, n=872, p<.01$ with high religiosity associated with low levels of un-conventional political participation. These results show that $\mathrm{H} 1$ hypothesis is rejected and $\mathrm{H} 2$ is accepted. Because after the correlation analysis it is seen that religiosity decreases all forms of political participation. Previously it is mentioned that religiosity is associated with conventional political participation in the literature. In addition, it is known that both political participation and religiosity increases with age. As a result of this it could be argued that due to our sample (university students), there is no relation found between religiosity and conventional political participation.

Table 3: Distribution of Religiosity according to Political Participation Scale

\begin{tabular}{|c|c|c|c|c|c|}
\hline & ROS & $\mathbf{N}$ & Mean & Std. Dev. & $\begin{array}{l}\text { Std. } \\
\text { Error }\end{array}$ \\
\hline \multirow{3}{*}{ Voting } & Not-participate & 119 & 6.19 & 2.735 & 0.251 \\
\hline & Participate & 657 & 6.48 & 2.806 & 0.109 \\
\hline & Not yet & 92 & 6.55 & 2.548 & 0.266 \\
\hline Working in a & Not-participate & 507 & 7.07 & 2.368 & 0.105 \\
\hline Campaign of a & Participate & 262 & 5.35 & 3.180 & 0.196 \\
\hline Party/candidate & Not yet & 99 & 6.17 & 2.580 & 0.259 \\
\hline \multirow{3}{*}{$\begin{array}{l}\text { Collect signature } \\
\text { signed a petition } \\
\text { for a candidate }\end{array}$} & Not-participate & 736 & 6.52 & 2.713 & 0.100 \\
\hline & Participate & 59 & 6.34 & 2.922 & 0.380 \\
\hline & Not yet & 73 & 5.89 & 3.152 & 0.369 \\
\hline \multirow{3}{*}{$\begin{array}{l}\text { Wear a sticker } \\
\text { or badge of a } \\
\text { political party. }\end{array}$} & Not-participate & 773 & 6.53 & 2.683 & 0.097 \\
\hline & Participate & 30 & 6.30 & 3.515 & 0.642 \\
\hline & Not yet & 65 & 5.55 & 3.245 & 0.403 \\
\hline \multirow{3}{*}{$\begin{array}{l}\text { Persuade } \\
\text { someone how } \\
\text { to vote }\end{array}$} & Not-participate & 739 & 6.66 & 2.636 & 0.097 \\
\hline & Participate & 44 & 5.80 & 3.282 & 0.495 \\
\hline & Not yet & 85 & 5.01 & 3.145 & 0.341 \\
\hline \multirow{3}{*}{$\begin{array}{l}\text { Youth branches } \\
\text { of a political } \\
\text { party }\end{array}$} & Not-participate & 766 & 6.37 & 2.738 & 0.099 \\
\hline & Participate & 41 & 7.56 & 2.829 & 0.442 \\
\hline & Not yet & 60 & 6.67 & 3.007 & 0.388 \\
\hline \multirow{3}{*}{$\begin{array}{l}\text { Political parties } \\
\text { except youth } \\
\text { branches }\end{array}$} & Not-participate & 817 & 6.47 & 2.746 & 0.096 \\
\hline & Participate & 17 & 5.35 & 3.334 & 0.809 \\
\hline & Not yet & 33 & 6.45 & 3.042 & 0.530 \\
\hline \multirow{3}{*}{$\begin{array}{l}\text { Writing a letter } \\
\text { of application }\end{array}$} & Not-participate & 292 & 6.66 & 2.563 & 0.150 \\
\hline & Participate & 388 & 6.15 & 2.940 & 0.149 \\
\hline & Not yet & 188 & 6.74 & 2.667 & 0.195 \\
\hline \multirow{3}{*}{$\begin{array}{l}\text { Signing a } \\
\text { petition }\end{array}$} & Not-participate & 335 & 7.06 & 2.260 & 0.123 \\
\hline & Participate & 426 & 5.80 & 3.008 & 0.146 \\
\hline & Not yet & 107 & 7.15 & 2.638 & 0.255 \\
\hline Joining a & Not-participate & 537 & 6.95 & 2.439 & 0.105 \\
\hline
\end{tabular}




\begin{tabular}{llcccc} 
boycott & Participate & 237 & 5.37 & 3.116 & 0.202 \\
& Not yet & 94 & 6.36 & 2.854 & 0.294 \\
\hline Attending a pol. & Not-participate & 561 & 6.91 & 2.409 & 0.102 \\
demonstration & Participate & 237 & 5.42 & 3.244 & 0.211 \\
Imeeting & Not yet & 70 & 6.27 & 2.807 & 0.336 \\
\hline Participating in & Not-participate & 808 & 6.65 & 2.641 & 0.093 \\
a protest march & Participate & 19 & 3.89 & 3.398 & 0.779 \\
& Not yet & 41 & 3.78 & 3.013 & 0.470 \\
\hline Organizing a & Not-participate & 753 & 6.46 & 2.745 & 0.100 \\
demonstration, & Participate & 59 & 6.80 & 2.670 & 0.348 \\
meeting & Not yet & 56 & 5.98 & 3.159 & 0.422 \\
\hline
\end{tabular}

Table 4: Correlations of Religiosity and PP

\begin{tabular}{lcccc}
\hline Variables & $\mathbf{1}$ & $\mathbf{2}$ & $\mathbf{3}$ & $\mathbf{4}$ \\
\hline 1-Religiosity & 1 & -0.060 & $-0.223^{\star \star}$ & $-0.198^{\star *}$ \\
2-Conventional & & 1 & $0.510^{* *}$ & $0.792^{* *}$ \\
3-Un-conventional & & & 1 & $0.883^{* *}$ \\
4-Total Political participation & & & & 1 \\
\hline
\end{tabular}

**. Correlation is significant at the 0.01 level (2-tailed).

\section{Conclusion}

The main objective of this study was to find out whether there was a relationship between religiosity and conventional and un-conventional form of political participation. As a result, the findings of the study indicate that religiosity is negatively associated with all forms of political participation. If an individual's religiosity increases, his/her political participation level in both conventional and un-conventional forms are decrease. Then it could be argued that religiosity can decrease the all forms of political participation for university students. As mentioned above it is known that both political participation and religiosity increases with age. Then it could be an expected result for university students.

\section{Ackowledgement}

The manuscript was generated by the author's Ph.D. thesis

\section{References}

Allport, G. W., Gillespie, J. M. and Young, J. (1948) "The Religion of the Post-War College Student", Journal of Psychology, vol. 25, 333.

Allport, G. W. (2004) Birey ve Dini / The Individual and His Religion, (Çev. Bilal Sambur), Elis Yayınları, Ankara

Argyle, M. and Beit-Hallahmi, B. (1975) The Social Psychology of Religion, Routledge and Kegan Paul.

Almond, G. and Verba, S. (1963) The Civic Culture: Political Attitudes and Democracy in Five Nations, Princeton University Press, NJ: Princeton.

Barnes, S. H., Kaase, M., Allerbeck, K. R., Farah, B. G., Heunks, F., Inglehart, R., Jennings,

M. K., Klingemann, H. D., Marsh, A. and Rosenmayr, L. (1979) Political Action: Mass Participation in Five Western Democracies, Sage Publications, C.A., Beverly Hills.

Batson, D. C., Schoenrade, P. A. and Ventis, L. W. (1993) Religion and the Individual: A Social-Psychological Perspective, Oxford University Press, New York.

Baykal, D. (1970) "Siyasal Katılıma: Bir Davranıs İncelemesi", Ankara Üniversitesi Siyasal Bilgiler Fakültesi Yayınları, No: 302, Ankara.

Conway, M. M. (2000) Political Participation in the United States, 3rd ed., A Division of Congressional Quarterly Inc., Washington D.C.

Cornwall, M. (1989) "The Determinants of Religious Behavior: A Theoretical Model and Empirical Test", Social Forces, Vol. 68, No. 2, pp. $572-592$.

Çapcıoğlu, İ. (2009) "Sosyo-politik Tutumlar ve Dindarlık: İlahiyat Fakülteleri Örneğinde Bir Alan Araştırması", Fırat Üniversitesi İlahiyat Fakültesi Dergisi, Vol. 14, No.1, pp.143-180.

Çarkoğlu, A. and Toprak, B. (2006) Değişen Türkiye'de Din Toplum ve Siyaset, Tesev Yayınları, İstanbul.

Çarkoğlu, A. and Kalaycıoğlu, E. (2009) "Türkiye'de Dindarlık: Uluslararası Bir Karşılaştırma", TUBITAK Report, pp. 1-43 http://research.sabanciuniv.edu/13119/1/Rapor_Kamu-dindarl\%C4\%B1k.pdf 
Dalton, R. J. (2002) Citizen Politics: Public Opinion and Political Parties in Advanced Industrial Democracies, 3rd. ed., Chatham House Publishers, New York.

Erdoğan, E. Türk Gençliği ve Siyasal Katılım: 1999-2003 http://www.urbanhobbit.net/PDF/typp_turkish.pdf

Erdoğan, E. (2001) "Türk Gençliği ve Siyasal Katılım Boyutları, Bir Katılım Endeksi Denemesi", Strateji Mori, Türk Gençliği ve Katılım, Katıl ve Geleceğini Yarat 1, Arı Düşünce ve Toplumsal Gelişim Derneği Yayını, İstanbul.

Esgin, A. (1999) "Gençlik ve Siyaset İlişkisinin Niteliği: Üniversite Gençliğinin Siyasal Yönelim ve Davranışlarını Belirleyen Etmenler", (Unpublished MSc Thesis), Cumhuriyet Üniversitesi Sosyal Bilimler Enstitüsü, Sivas.

Fromm, E. (1997) Sahip olmak ya da Olmak, (Çev. Aydın Arıtan), Arıtan Yayınevi, İstanbul.

Günay, Ü. (2006) Dindarlığın Sosyolojisi, Dindarlığın Sosyo-Psikolojisi, 1st ed., Ünver Günay, Celaleddin Çelik, Karahan Kitabevi, Adana.

Hood, R. W. Jr., Hill, P. C. and Spilka, B. (2009) The Psychology of Religion: An Empirical Approach, The Guilford Press, 4th ed., New York.

Hökelekli, H. (2010) Din Psikolojisine Giriş, Dem Yayınları, 1st ed., İstanbul

Hülür, H. and Kalender, A. (2003) Sosyo-Politik Tutumlar ve Din: Konya Araştırması, Çizgi Kitabevi, 1st ed., Konya.

Kalaycıoğlu, E. (1983) "Karşılaştırmalı Siyasal Katılma: Siyasal Eylemin Kökenleri Üzerine Bir İnceleme", İstanbul Üniversitesi Siyasal Bilimler Fakültesi Yayını, İstanbul.

Köktaş, M. E. (1993) Türkiye'de Dini Hayat, İşaret Yayınları, 1st ed., İstanbul.

Mehmedoğlu, A. U. (2004) Kişilik ve Din, Dem Yayınları, İstanbul.

Milbrath, L. W. (1965) Political Participation: How and Why Do People Get Involved in Politics?, 2nd ed., Rand McNally \& Company, Chicago.

Miller, A. S. and Hoffman, J. P. (1995) "Risk and Religion: An Explanation of Gender Differences in Religiosity", Journal for the Scientific Study of Religion, Vol.34, No.1, pp. 63-75.

Mutlu, K. (1989) "Bir Dindarlik Ölçeği: Sosyoloji'de Yöntem Uzerine Bir Tartışma", İslami Arastirmalar, V.3, No.4, pp.194-199.

Mutlu, K. (1996) "Examining Religious Beliefs among University Students in Ankara", The British Journal of Sociology, Vol. 47, No. 2, pp. 353-359.

Onay, A. (2004) Dindarlık, Etkileşim ve Değişim Üniversite Öğrencileri Örneklemi, Dem Yayınları, İstanbul.

Ozankaya, Ö. (1966) "Üniversite Öğrencilerinin Siyasal Yönelimleri”, Üniversitesi Siyasal Bilimler Fakültesi Yayınları, Ankara.

Parlak, İ. (1999) "Türkiye'de Gençlik ve Siyaset: H.Ü. Beytepe Kampüsü Örneği”, (Unpublished Msc Thesis), Hacettepe Üniversitesi, Sosyal Bilimler Enstitüsü, Ankara.

Quintelier, E. (2007) "Differences in Political Participation between Young and Old People", Contemporary Politics, Vol.13, No. 2, pp. $165-180$.

Secret, P. E., Johnson, J. B. and Forrest, A. W. (1990) "The Impact of Religiosity on Political Participation and Membership in Voluntary Association among Black and White Americans", Journal of Black Studies, Vol. 21, No. 1, pp. 87-102.

Spilka, B., Hood, Jr. R. W. and Gorsuch, R. L. (1985) The Psychology of Religion: An empirical Approach, Prentice-Hall Inc. Englewood Cliffs, New Jersey.

Şahin, A. (1999) "Illahiyat, Tıp ve Mühendislik Fakültelerinde Okuyan Öğrencilerde Dini Hayatın Boyutları Üzerine Karşılaştırmalı Bir Araştırma", (Unpublished PhD. Thesis), okuz Eylül Üniversitesi Sosyal Bilimler Enstitüsü, İzmir.

Tatar, T. (2003) "Malatya'da Siyasal Katılım: Karşılaştırmalı Bir Analiz", Fırat Üniversitesi Sosyal Bilimler Dergisi, Vol.13, No.1, pp.331350.

The Gallup Organization (2007) "Young Europeans: Survey among Young People Aged Between 15-30 in the European Union", Flash Eurobarometer 202 http://ec.europa.eu/public_opinion/flash/fl_202_sum_en.pdf.

TÜSIAD (2001) "Seçim Sistemi ve Siyasi Partiler Araştırması", Ana Rapor, Vol.2, (No. TÜSIAD-T/2001-11/312). http://www.tusiad.org/ rsc/shared/file/ssspaCilt2.pdf

Uysal, V. (1996) "Din Psikolojisi Açısından Dini Tutum Davranış ve Şahsiyet Özellikleri”, M.Ü. İlahiyat Fakültesi Vakfı Yayınları No.111, İstanbul.

Van Deth, J. W. (2001) "Studying Political Participation: Towards a Theory of Everything?" Paper presented at the ECPR Joint Sessions of Workshop 'Electronic democracy: mobilization, organization and participation via new ICT's', Grenoble, 6-11 April.

Verba, S. and Nie, N. H. (1972) Participation in America: Social Equality and Political Democracy, Harper \& Row, New York.

Vernon, G. M. (1962a) "Measuring Religion: Two Methods Compared”, Review of Religious Research, Vol.3, No.4, pp.159-165.

Vernon, G. M. (1962b) Sociology of Religion, McGraw-Hill Book Company.

Wolfinger, R. E. and Steven J. R. (1980) Who Votes?, Yale University Press, New Haven. 